\title{
A TEACHER'S DECISION-MAKING PROCESS IN AN ELEMENTARY SCHOOL EFL EDUCATION
}

\author{
ERI OSADA ${ }^{1}$ \\ Kokugakuin University (Japan)
}

\section{RESUMEN}

Este estudio de casos investiga el proceso de toma de decisiones de un docente de inglés como lengua extranjera (EFL) en una escuela de educación primaria en Japón. El participante era un profesor masculino que rondaba los cuarenta años (y solía trabajar en el extranjero, por lo que tenía experiencia internacional) con poca experiencia en la enseñanza del inglés. En 2011 tuvo la oportunidad de enseñar en la universidad durante un año, al tiempo que impartía clases experimentales de inglés en una escuela de primaria. El investigador observó las cuatro clases que impartió con un profesor nativo de inglés, tomó notas y se establecieron debates con el docente antes y después de dichas clases. Las clases, así como estos debates, se grabaron digitalmente. Los datos de la observación fueron transcritos y analizados con referencia a las planificaciones de aula originales, los datos del debate y las notas de campo. Los resultados mostraron que algunos factores, como por ejemplo el nivel de perfeccionamiento inadecuado en inglés, tenían cierto impacto en sus decisiones de planificación para subsiguientes clases, y que su decisión sobre la cantidad deseada de uso de la lengua meta estaba influenciada por sus creencias sobre la educación en lengua japonesa, que es su especialidad.

Palabras clave: Escuela primaria, inglés para fines específicos (EFL), toma de decisiones, cognición del docente.

\begin{abstract}
This is a case study that investigated a teacher's decision-making process regarding EFL education in a Japanese elementary school. The participant was a male homeroom teacher in his forties. Although he was experienced as a homeroom teacher (and he used to work overseas, so he had international experience), he was rather inexperienced in teaching English. In 2011, he had a chance to study at a university for a year, and also conducted experimental English lessons in an elementary school. The researcher observed the four lessons he conducted with a native speaker of English, took field notes, and had pre-class and post-class discussions with him. The lessons as well as the discussions were digitally recorded. The observation data were later transcribed and analyzed with reference to the original lesson plans, discussion data, and field notes. The results showed that several factors, such as his inadequate English proficiency, his classroom practice experience as a homeroom teacher, and the students' postclass reflections, had an impact on his decisions when planning the next lessons, and that his decision about the desired amount of target language use was influenced by his beliefs about the Japanese language education, which is his specialty.
\end{abstract}

Key words: Elementary school, EFL, decision-making, teacher-cognition.

\footnotetext{
1 E-mail: osadae@kokugakuin.ac.jp
} 


\section{Introduction}

The English program was officially implemented in Japanese elementary schools in 2011. This program, which is named "Foreign Language Activities," is now a compulsory subject in Grades 5 and 6, but is not a core subject in the way that Japanese, math, or science are. After several years of English being taught at elementary schools, the Ministry of Education, Culture, Sports, Science and Technology (MEXT) is currently planning to implement English in Grades 3 and 4, and to upgrade Foreign Language Activities to a core subject for Grade 5 and 6 students. The biggest issue in terms of making English a core subject is who will teach it. Currently, the curriculum guidelines indicate that homeroom teachers, who teach all the subjects, should play the primary role in conducting English lessons. They manage to teach English with the aid of an assistant language teacher (ALT), even though they were not trained to teach it when they were pre-service teachers. However, if English becomes a core subject, homeroom teachers should have certain knowledge and skills about teaching it. Therefore, the current study tries to examine a homeroom teacher's decision-making process through observation, field notes, and discussions with him.

\section{Elementary school English education in Japan}

According to the curriculum guidelines for "Foreign Language Activities," the overall objective is to form the foundation of pupils' communication abilities through foreign languages. The guidelines say that foundation should be pursued via the understanding of languages and cultures through various experiences, a positive attitude toward communication, and familiarity with the sounds and basic expressions of foreign languages. The guidelines also state that too much of a focus on gaining language skills is not appropriate, especially in reading and writing. In fact, only the comprehension of the letters of the alphabet letters is included in the textbooks.

In junior and senior high schools, a Japanese teacher of English (JTE) who has a teacher's license in English usually teaches alone, and sometimes co-teaches with an ALT, who is a native or near-native speaker of English. On the other hand, elementary schools have various types of teaching styles. If a local government is rich enough to afford to hire an ALT, a homeroom teacher (HRT) can teach with him/her in every lesson, while a JTE might be hired and work with an HRT in some areas. The majority of the schools can enjoy an ALT's visit, but the frequency of their visits varies depending on the local government budget. In other schools, an HRT teaches without anyone else's help. If English education becomes a compulsory core subject and there is to be a new focus on pupils gaining language skills, teachers would need more teaching skills than ever.

The model which Borg (2006) established shows that teacher cognition is affected by a teacher's own experience at schools, his/her professional coursework in a pre-service teacher education, and contextual factors such as previous and current classroom practices and their own teaching practicum (Graph 1). However, many of the Japanese homeroom teachers have had no experience of learning English when they were elementary school students. Nor were they trained for teaching English, and in-service training sessions are rarely provided. On the contrary, they are professional as to primary education because they have been trained and licensed as a primary school teacher and therefore their skills to teach children would have a positive impact on a foreign language teaching. 


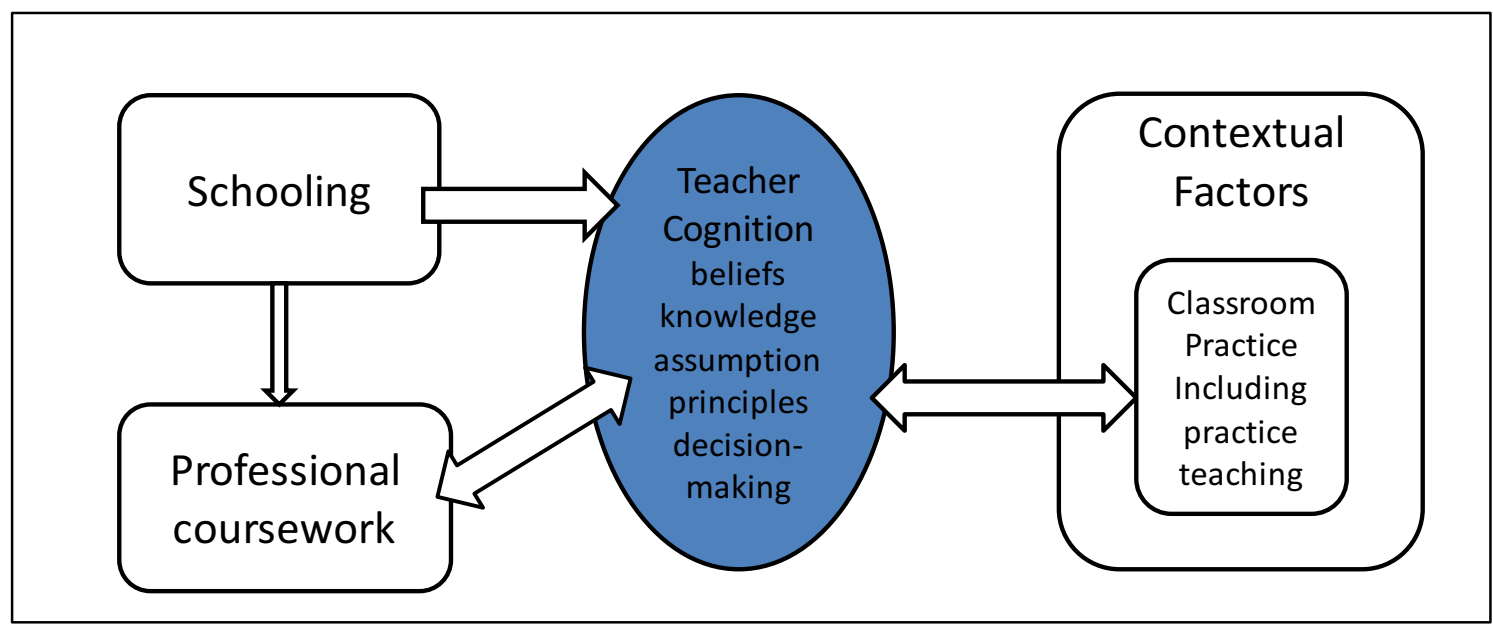

Graph 1. Borg's model of teacher cognition (2006)

Borg states that a key role for teacher cognition research is to support teacher learning at both preservice and in-service levels; this case study would contribute to teacher education by investigating a teacher's decision-making process.

\section{Literature review}

This section will address the previous literature on decision-making processes and teacher cognition.

\subsection{Types of decisions}

Woods (1989) proposed two types of decisions: sequential decisions and hierarchical decisions. A sequential decision is one which follows another but is independent of the previous decision, whereas a hierarchical decision is one which is intended to achieve the goals of a previous decision. Richards and Lockhart (1994: 78) put decisions into three categories: planning decisions, interactive decisions, and evaluative decisions. Planning decisions are made before classes, interactive decisions are made during classes, and evaluative decisions are made after classes. Inaba (2013), using Richards and Lockhart's types of decisions, shows some examples in each category. Before class, teachers make decisions about goals, materials, and activities. In class, teachers make decisions about time management, which student to call on, and how and when to give feedback. After class, they evaluate the lesson so as to make the next lesson better. As her research was done in junior and senior high schools, I added two examples of decisions for an elementary school setting: how to cooperate with an ALT as a planning decision, and which language to use as an interactive decision (Graph 2). As for the first one, team teaching with an ALT is quite common but nevertheless sometimes problematic in elementary school English classes. Regarding the teacher's language use in class, the senior high school curriculum guidelines stipulate that English class should be taught in English. It is probable that the next curriculum guidelines for junior high school English education will have the same requirement. Although there is no mention about a teacher's classroom use of language in the current elementary school curriculum guidelines for "Foreign Language Activities," it might be the case that how much English versus Japanese should be used will be controversial. 


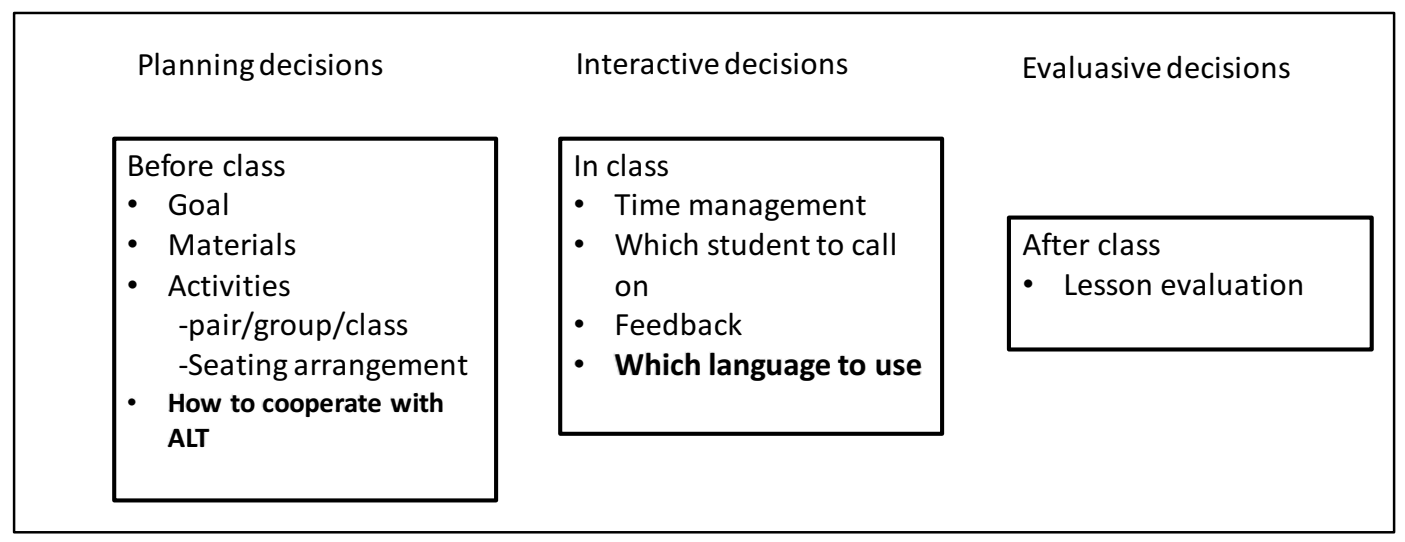

Graph 2. Three types of decisions, adapted from Inaba (2013)

\subsection{Teacher cognition}

There are a large number of studies on language teacher cognition (e.g. Johnson, 1992; Nunan, 1996; Bailey, 1996; Golombek, 1998; Tsang, 2004). Bailey (1996), for example, conducted a study of ESL teachers' decision-making. She obtained copies of lesson plans, videotaped their lessons, took field notes, and then interviewed the teachers. During lessons, the teachers in this study changed their plans

- if an opportunity arose to serve the common good

- when an unexpected opportunity arose to teach something timely and significant

- if an alternative arose that would apparently accomplish the same goals better than the teacher's planning decisions would have done

- when deviating from their lesson plans would better accommodate the students' learning styles.

They also changed their lesson plans in order to promote students' involvement, or to keep the more verbal learners from dominating activities and to encourage the less verbally active students to participate more.

On the other hand, there are few studies on decision-making in English education in Japan. The result of Inaba (2013) shows that the examined teachers' decisions were made based on

- the goals set either by school or individually

- teachers' beliefs from their learning experiences, knowledge or values

- students' current learning conditions

- relationship with class or an individual student

- educational policy of school

It seems that teachers make decisions not only based on their experiences and their beliefs from their previous practices, but also by the ongoing class atmosphere, including students' learning behaviors. Using the Borg (2006) teacher cognition model and the Inaba (2013) three types of decisions as theoretical frameworks, this research will seek answers to the following questions.

1. What kind of decisions does a homeroom teacher make?

2. What does a homeroom teacher base decisions on when he plans lessons, while he is teaching, and after he finishes the lessons? 


\section{Study}

\subsection{Types of decisions}

The participant is a male teacher, Teacher $A$, who had been an elementary school teacher for seventeen years. He had had an experience teaching at a Japanese school in an Asian country for three years, while living with his family. When I conducted this study, he had been allowed to leave his school for one year and study "Foreign Language Activities" at a university. He was a pseudo-homeroom teacher, which means he was not the students' real homeroom teacher because he was away from his school work. However, he acted like a homeroom teacher, including co-teaching with an ALT while this study was conducted. He came to study at the university where I worked so as to examine the possibility of introducing phonological awareness (PA) activities to elementary school English education. In order to add some PA activities, he had to modify the lesson plans which were established by the government. This necessitated that he make some planning decisions, and I examined these by comparing the original lesson plans with his own lesson plans.

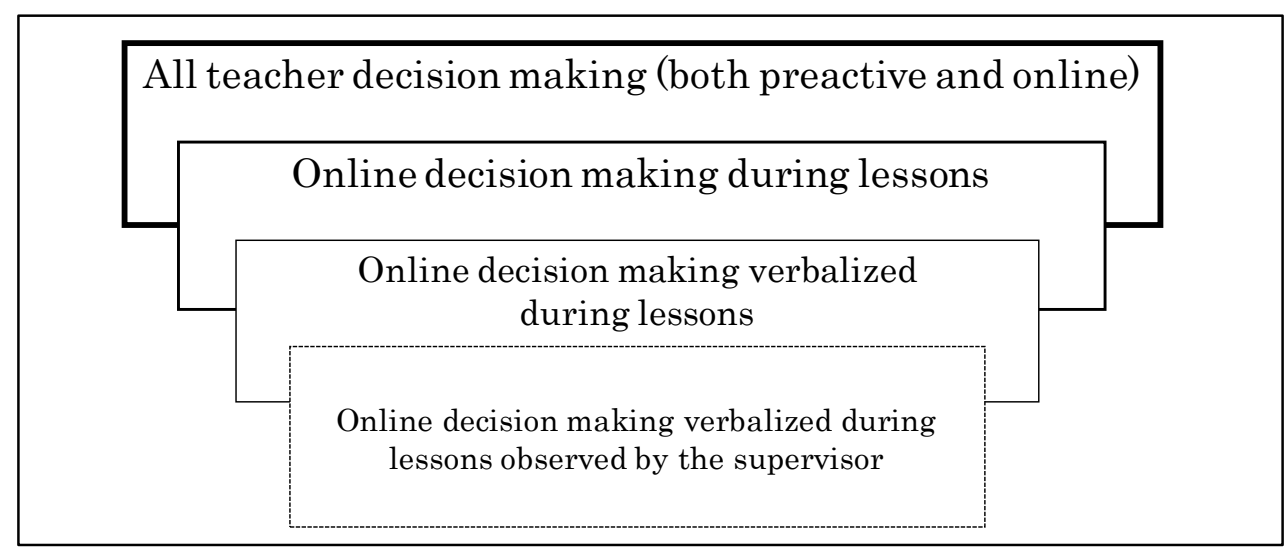

Graph 3. Decision-making hierarchy (Bailey, 2006)

Bailey (2006) indicates that it is difficult to observe "online", which some other researchers call "interactive" or "in-class" decision-making, and therefore I not only videotaped the classes and took field notes, but also had discussions about lessons with the teacher before and after the lessons (Graph 3). The discussions before class involved the teacher showing me his lesson plans and explaining them to me, and then I asked questions if I had any. Those after class were so-called stimulated recall. The stimulated recall method is a type of retrospective report. The participants are interviewed by a researcher who prompts recalls about certain events which occurred in the classroom. Even though stimulated recall is usually done with video-watching, I couldn't use a video during discussions because of the time constraint. Consequently, I asked questions based on my field notes and Teacher A answered.

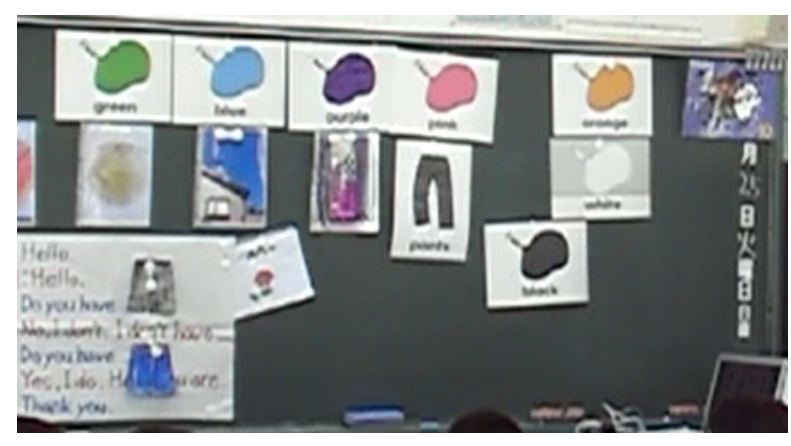

Graph 4. Teaching materials on the blackboard 


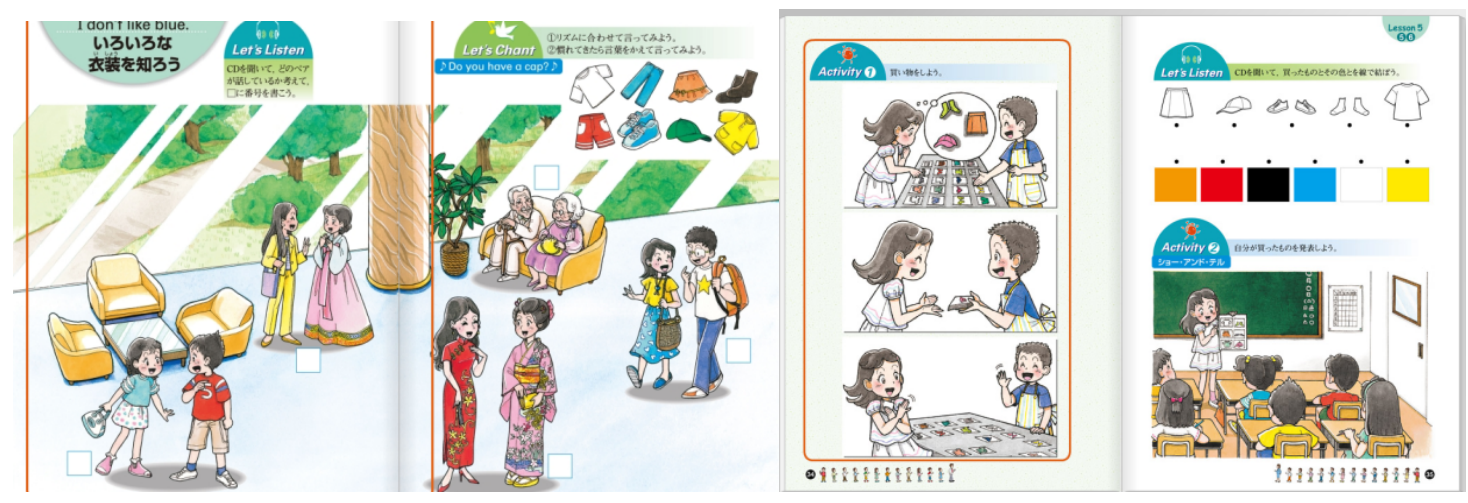

Graph 5. Eigo note 1 (MEXT, 2009)

\subsection{Results and discussions}

\subsubsection{Planning decisions}

\section{Changing contents in lesson plans}

Table 1 shows the original unit plan provided by MEXT. The goal is that students will express what they want and then introduce their design to their classmates. He not only set these goals but also an additional goal for students' PA. There are four lessons in this unit. Based on this unit plan, Teacher A carefully made his own unit syllabus as well as each lesson plan. Since he needed to make room to add PA activities, he decided to delete some other activities. The original first lesson plan had three activities, but Teacher A modified the contents of the second activity and eliminated the third activity. In the second lesson, he modified "Let's listen" and decided not to cover Activity 1. In the third and fourth lessons, he planned to skip "Let's listen," while in the fourth lesson he changed the style of "Let's chant." The reason that he decided to skip the listening comprehension quizzes listed in the teachers' manual was probably that he co-taught with a native speaker of English. The textbook provided by MEXT offered some listening activities in order to give students, who had little opportunity to experience contact with a foreign teacher, a chance to hear native speakers' speech. In Teacher A's case, he did not in fact need such materials. In addition to omitting some activities, he tried to attract his students more effectively by using an iPad instead of the pictures in the textbook. He considered an intercultural activity in the first lesson of every unit to be indispensable, but he thought the pictures in the textbook were not varied enough to attract his students. So instead of working on the activity shown in the textbook, he showed 15 different clothes in 15 different countries on the iPad. He mentioned that "I would expect my students to get interested in foreign countries through knowing various kinds of clothes in the world." As referenced earlier, he added some PA activities to the provided plans. One of those activities is "swattering," in which students swat the cards which their teachers say. His students used to use their hands when they played such games, but after learning a new way of playing it at the university, he changed the rule and he had his students use their pencils instead of their hands.

Table 1. Activities on the original lesson plans (Modified version of MEXT, 2009)

\begin{tabular}{|c|c|c|c|}
\hline LESSON 1 & LESSON 2 & LESSON 3 & LESSON 4 \\
\hline $\begin{array}{c}\text { Let's Listen } \\
\text { (Which pair is talking?) }\end{array}$ & Let's chant! & Let's chant! & Let's chant! \\
\hline $\begin{array}{c}\text { Activity } \\
\text { (What kind of clothes do } \\
\text { you want to try on?) }\end{array}$ & $\begin{array}{c}\text { Activity } \\
\text { (Boy/girl dressed in your } \\
\text { favorite clothes) }\end{array}$ & $\begin{array}{c}\text { Let's listen! } \\
\text { (What items are there?) }\end{array}$ & $\begin{array}{c}\text { (Draw lines from items } \\
\text { to colors) }\end{array}$ \\
\hline
\end{tabular}




\begin{tabular}{|l|c|c|c|}
\hline Let's chant! & $\begin{array}{c}\text { Let's listen! } \\
\text { (What items are there?) }\end{array}$ & $\begin{array}{c}\text { Activity 1 } \\
\text { (Let's play a shopping } \\
\text { game.) }\end{array}$ & $\begin{array}{c}\text { Activity 2 } \\
\text { (Show and tell) }\end{array}$ \\
\hline & $\begin{array}{c}\text { Activity } \\
\text { (preparation for a } \\
\text { shopping game) }\end{array}$ & & \\
\hline
\end{tabular}

\section{Time constraints}

In the fourth lesson, he changed the format of the activity in order to save time and to prevent the students from getting bored. He made four groups for presentations, instead of dividing the students into two groups. If he had divided the students into only two groups, there would have been about twenty students in each group, which would have taken more time. He also had the ALT observe two groups while he was in charge of the rest. It would have seemed easier for the teachers to control just one group, but he and the ALT carefully stood between the two groups and watched them.

"If you had ten students give a one-minute presentation, it would not take only ten minutes, but more than ten minutes because you would have to think of the time for explanation as well as the time the students would take to go to the front before the presentation, and go back to his/her seat after the presentation. Such time for classroom management can only be estimated by your experience of teaching."

And in the last discussion session, he also confessed, "If I had been their homeroom teacher, I could have done better time management under better classroom control."

\subsubsection{Interactive decisions}

Richards and Lockhart (1994) state that teaching is essentially a thinking process. Teachers make a decision every single minute. Some salient examples will be shown in this section.

\section{Time Allocation}

Although he attempted to allocate adequate time to each activity every time he created a lesson plan, the lessons sometimes did not go as planned. In the second lesson, the previous activity happened to take more time than planned, and therefore "Let's listen" was eliminated. On the other hand, he gained an extra five minutes for oral practice because he skipped the listening practice. On another occasion, the bell rang for the end of the class; that time, "Reflection time" was eliminated in the first lesson, and PA review practice was eliminated in the third lesson.

\section{Language choice}

Teacher A's original specialty is teaching the Japanese language, even though homeroom teachers teach almost all the subjects in Japanese elementary schools. In discussions with him, he seemed to be aware of the language use issue.

"I intentionally used more English in the second lesson than in the first one. Students react immediately to their homeroom teacher because they are familiar with their homeroom teacher's voice. On the contrary, the students in that class were not familiar with my voice. Moreover, their homeroom teacher is female. I thought it might be hard for them in the first lesson to react to my instruction, and much harder in English. In the second lesson, however, I thought they got familiar with my voice and could understand me."

"As a teacher who majored in Japanese, I believe language teachers are responsible for providing as much comprehensible input for their students in English lessons as possible. l'd like to conduct $80 \%$ of each English lesson in English, but I can't because of my lack of English ability." 
In the SLA (Second Language Acquisition) classes that he attended at the university, he learned that input should be meaningful to the students, and that classroom English in particular should be maximized, as it is a comprehensible and meaningful input. That may be why he relied on classroom English. On the other hand, in order to facilitate students' understanding, he especially used Japanese, when he explained how to play games. In the excerpt below, he used both Japanese and English.

HRT: $\quad$ Repeat after me. likana? [Are you ready?] Group 1, 3, 5. Hello.

G1, 3, 5:

(Silence)

HRT:

Are?[Oh?] Repeat after me. Group 1, 3, 5.

OK? Hello. ("let me hear you" gesture)

Class: Hello.

HRT: $\quad$ Only Group 1, 3, 5. Daijobu? [Are you all right?] Hello.

G1, 3, 5: Hello.

During the instruction, he kept speaking in English while using gestures, whereas he used Japanese when he wanted to express his emotions.

\subsubsection{Evaluative decisions}

Two decisions were found to be evaluative. One was that Teacher A did a different PA activity from the one planned earlier (Lesson 3) to make the lesson more attractive to his students, taking into account the students' reflections from the previous lessons. He planned to play "Rider's joy game," which was done in the second lesson, in the third lesson as well. However, as the students didn't seem to enjoy it in the second lesson, he changed the activity into a "Snail talk, get a tail" game when he revised the plan of the third lesson. Unfortunately, he almost ran out of time before the "Snail talk, get a tail" game was introduced, and he decided to skip it and save time for the students' reflections, and therefore it could not be verified whether this change would have been effective or not. The other evaluative decision was the formation of the activity. Originally, he planned to have his students practice in chorus all together and then split into two groups. However, the students' performance in the previous lesson led him to change his mind, and he skipped the whole class practice. He said, "In the previous lesson, the students did a better job than I had expected. So, I decided to skip the choral practice and divide them into two groups in this lesson."

\subsection{Further discussions}

The previous section discussed the results in terms of decision-making process, while in this section the results will be analyzed in the light of teacher cognition. Graph 6 shows Teacher A's decision-making process. As mentioned earlier, people around his age did not have any experience of learning English in their elementary school, and when he was in pre-service teacher education course, he never learned how to teach a foreign language. However, as he specialized in Japanese language pedagogy, he had knowledge about teaching a language. In addition, he had a chance to learn SLA or early childhood foreign language methodologies in a university for a year. Those experiences apparently had an impact on his decisions. As an experienced homeroom teacher, he carefully watched children's performance and behavior, which affected the next lesson. However, he could not accomplish his ideal use of languages because of his lack of English ability. In his case, he worked with an ALT who was a native speaker of English. Teacher A made use of the ALT as a provider of authentic input, and yet he did not think that the amount of his own input in the target language was enough. 


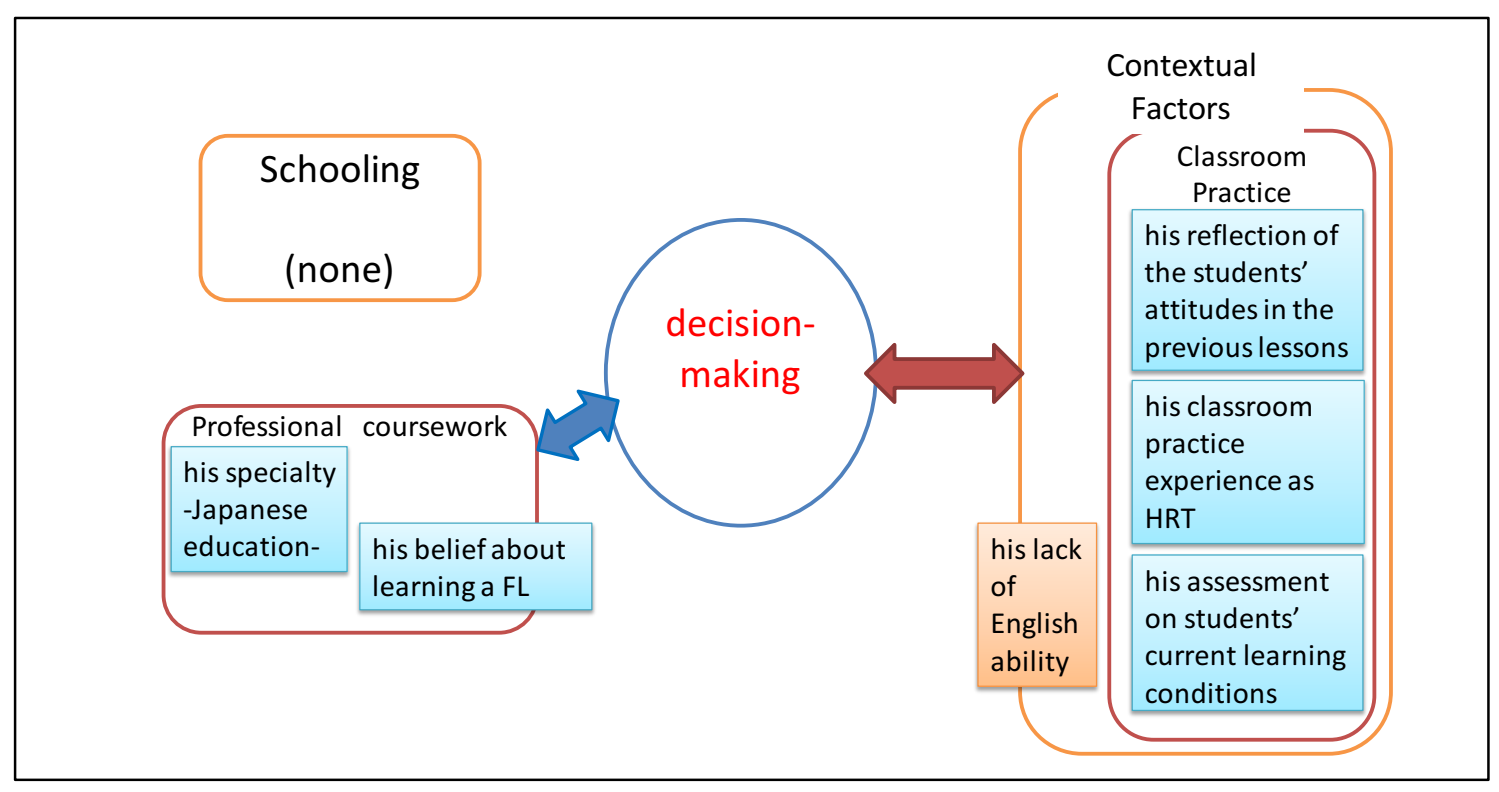

Graph 6. Teacher A's cognition

In reference to the factors which exerted influence on his decision-making, his personal experience overseas is also relevant. He lived in a foreign country for three years and he learned to speak the local language. His family members, his wife and two young children, also learned it, and so he must have seen how people learn a foreign language from the beginning. His perceptions of the importance of sound and intercultural understanding for learning a foreign language might stem from his personal experience. He was unusual in this sense, compared with most of the other homeroom teachers.

\section{Conclusions}

There were several decisions found and analyzed in this study which could be classified into two groups, specifically positive and negative decisions. Teacher A's knowledge and experience as a homeroom teacher seemed to have a positive impact on his teaching even in English, whereas his lack of proficiency in English had a negative impact on his ability to teach in that language. Teacher A added some PA activities that he considered useful for his students. Then he changed some part of each lesson plan to facilitate his students' understanding, to help his students enjoy English classes, or to save time. As for language use, he did not use as much English as he expected because of his lack of English proficiency.

He was lucky enough to take some courses related to SLA and early childhood foreign language education at a university, but most of the current in-service teachers lack both professional coursework and the chance to improve their English skills. These deficiencies might cause them trouble when they make decisions in English classes. Therefore, it is important that the in-service and pre-service teacher training should provide chances to obtain knowledge of theory and practice about teaching a foreign language, and to improve English skills. Lastly, teachers who are involved in teaching a foreign language might need some experiences of intercultural contact, which is my next research topic.

There is a limitation in this study, which is that it examined only one homeroom teacher and it cannot be generalized. In order to make the results transferrable, it is necessary to conduct more research on other cases.

\section{Acknowledgement}

This work was supported by JSPS KAKENHI Grant Number 23520756, titled "Teachers' decisionmaking process for improving children's communicative competence in Foreign Language Activities." I would like to express my gratitude to Teacher A, who kindly agreed to be a participant in my research. 


\section{References}

Bailey, K. M. (1996). The best laid plans: Teachers' in-class decisions to depart from their lesson plans. In Kathleen M. Bailey and David Nunan (Eds.), Voices from the language classroom (pp. 15-40). Cambridge: Cambridge University Press.

Bailey, K. M. (2006). Language Teacher Supervision. A Case-Based Approach. Cambridge: Cambridge University Press.

Borg, S. (2006). Teacher Cognition and Language Education. London: Continuum.

Golombek, P. R. (1998). A study of language teachers' personal practical knowledge. TESOL Quarterly, 32(3), pp. 447-464.

Inaba, M. (2013). Gaikokugono jugyoni okeru kyoshino ishiketteino hohoto konkyowo shosatsusuru [Reflecting teachers' decision-making methods and reasons in foreign language classes]. Communication noryokuwo hagukumu shochukono eigokyoiku [English education for fostering communicative competences in elementary, junior high, and high school] (pp.13-27). Aichi: Aichi University of Education.

Johnson, K. E. (1992). Learning to teach: Instructional actions and decisions of pre-service ESL teachers. TESOL Quarterly, 24 (3), pp. 507-535.

MEXT. (2009a). Shidosho 1. Tokyo: MEXT.

MEXT. (2009b). Eigo Note 1. Tokyo: MEXT

MEXT. (2010). Foreign Language Activities. Retrieved in August, 2014 from http://www.mext.go.jp/component/a_menu/education/micro_detail/_icsFiles/afieldfile/2010/10/20/1 261037_12.pdf

Nunan, D. (1996). Hidden voices: Insiders' perspectives on classroom interaction. In Kathleen. M. Bailey and David Nunan (Eds.), Voices from the Language Classroom (pp. 41-56). Cambridge: Cambridge University Press.

Richards, J. C. \& Lockhart, C. (1994). Reflective teaching in second language classrooms. Cambridge: Cambridge University Press.

Received: 26/02/2016

Accepted: 24/06/2016 